\title{
MENYEIMBANGKAN IQ, EQ, SQ DALAM PENDIDIKAN BERWAJAH INSANI
}

Oleb: Mansur*

Abstract

Education is as one a way bequatbed a value, which can become guidance to face our life and also it can improve our fate and buman civilization. To face globalization era should be strove education which bas the ability to develop intellectual intelegency, emotional intelegency and spiritual intelegency. Therefore education is not only develop intelectual intelegency, which gives negative effect but also it is not able to solve the buman problem in globalization era. If we see the phenomena that many destructions bappen in this world because of the model of education which based on intellectual intelegengy and be oriented toward materialistic. That is wby education model needs to make balancing intellectual intelegency, emotional intelegency and spiritual intelegency. So education which is needed by buman being is intellectual intelegency, emotional intelegency and spiritual intelegency as a unit in improving buman quality.

أصبحت التربية وسيلة لتوريث القيم المادي إلى تنظيم اللحياة وتحسينها وتأسيس الحضارة للإنسان ، وبلون التربية فالإنسان في عصر الحاضر لا يختلف مع الإنسان الذين عاشوا في عصر الماضي أو الإنسان المستقبل لا يختلف مع الإنسان في عصر الحالي بل هم أسوأ من ناحية الموارد البشرية. ولمواجهة العصر المنفتح يكتاج إلى نظام تربية متصفة بالإنسانية التي تطور مهارة العقل والروح والوجدان في آن واحل. و التربية اليّي تودي إلى تطوير مهارة العقل وحلدها عاجزة عن إتيان الحلول لمشاكل البحتهع بل ليس فن المستحيل أن تتولد مشاكل أخرى وأكبر اليتي تلدم حياة المحتمع لنلك تمس الملاجة إلى نظلم التربية التي توازن المهارات المابقة وتلعمى بعضها مع بعض لتأسيس الموارد البشترية.

Kata Kunci: $I Q-E Q-S Q$ - Pendidikan

* Doktor Universitas Islam Negeri Yogyakarta, dosen Sekolah Tinggi Agama Islam Negeri (STAIN) Salatiga. 


\section{A. Pendabuluan}

Kondisi pendidikan yang terkesan fragmentaris atau terpecah-pecah, ${ }^{1} \mathrm{di}$ antaranya disebabkan karena tujuan pendidikan cenderung berorientasi pada kepentingan pemerintah dengan dalih mencapai target pembangunan yakni mengejar pertumbuhan perekonomian bangsa. Padahal pendidikan adalah merupakan suatu upaya mewariskan nilai, yang akan menjadi penolong dan penuntun dalam menjalani kehidupan dan sekaligus untuk memperbaiki nasib dan peradaban umat manusia. ${ }^{2}$ Tanpa pendidikan, maka generasi sekarang tidak akan berbeda dengan generasi masa lampau atau manusia yang akan datang tidak akan berbeda dengan manusia sekarang bahkan mungkin saja malab lebih jelek kualitasnya. $^{3}$

Secara ekstrim dapat dikatakan bahwa maju mundurnya atau baik buruknya peradaban suatu masyarakat, suatu bangsa akan sangat ditentukan oleh bagaimana pendidikan yang dijalani atau ditempuh oleh masyarakat bangsa itu. ${ }^{4}$ Jadi maju mundurnya suatu kaum sangat bergantung sebagian besar kepada pendidikan yang berlaku di kalangan mereka. ${ }^{5}$ Masyarakat modern dalam suatu bangsa dapat diwujudkan dengan melalui peningkatan pendidikannya, hal itu berlaku juga bagi bangsa Indonesia yang mayoritas penduduknya beragama Islam. ${ }^{6}$ Tepat dikatakan oleh Ghulam Nabi Saqib, education may be used to belp modernize a society. ${ }^{7} \mathrm{Dal}$ am halaman lain juga dikatakan, education, therefore is certainly the key to the modernization of Muslim societies. ${ }^{8}$

Dengan demikian masyarakat madani dalam suatu bangsa dapat diwujudkan dengan melalui peningkatan pendidikan umat dalam suatu bangsa, hal itu berlaku juga bagi bangsa Indonesia yang mayoritas penduduknya beragama Islam. ${ }^{9}$ Oleh karena itu tepat dikatakan John Dewey, pendidikan diartikan sebagai, social continuity of life. Pendidikan juga diartikan, it more narrowly as transmission from some persons to others of the skills, the arts and the sciences. ${ }^{10}$ Pada umumnya sistem pendidikan

'Kurang adanya kesinambungan, betkelanjutan dari pendidikan rendah ke jenjang pendidikan tinggi.

${ }^{2}$ Mansur (2005), Mendidik Andk Sejak dalam Kandungan, Yogyakarta: Mitra Pustaka, p. 1.

${ }^{3}$ Mansur (2001), Diskursus Pendidikan Islam, Yogyakarta: Global Pustaka Utama, p. 1. p. 3.

${ }^{4}$ Mansur (2004), Sejarah Sarekat Islam dan Pendidikan Bangsa, Yogyakarta: Pustaka Pelajar,

${ }^{5}$ M. Natsir (1973), Kapita Selekta, Jakarta: Bulan Bintang, p. 77.

- Azwar Anas (1993), Kompetensi Perguruan Tinggi Islam Swasta dalam Pembangunan Jangke Panjang Tabap Kedna, Yogyakarta: Tiara Wacana, p. xiii.

${ }^{7}$ Ghulam Nabi Saqib (1983), Modernization of Muslim Education in Egypt, Pakistan, and Turkey, Lahore: Islamic Book Service, p. viii.

${ }^{8}$ Ibid., p. 296.

${ }^{9}$ Azwar Anas (1993), op.cit., p. xiii.

${ }^{10}$ Kingsley Ptice (1965), Edwcational and Philosophical Thozght, USA: Allyn and Bacon, p. 4. 
nasional dewasa ini dihadapkan berbagai tantangan, baik tantangan internal

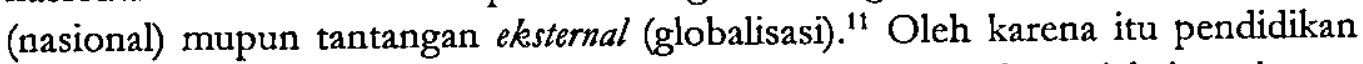
agar mampu menghadapi globalisasi, idealnya pendidikan berwajah insani yang kurikulumnya berorientasi kepentingan peserta didik, kebutuhan masyarakat atau pasar kerja dan tetap dalam perspektif kepentingan manusia dan bangsa Indonesia.

Selain gambaran orientasi tujuan pendidikan di atas juga dilatarbelakangi adanya dikotomi ilmu pengetahuan dan agama, sehingga tidak terdapat hubungan fungsional dan terjalin dalam kesatuan integral. Menurut konsep lslam bahwa ilmu itu bagian dari agama, oleh karena itu kurikulum hendaknya berisi ilmu-ilmu umum yang bersumber dari nilai-nilai agama dan dikembangkan dalam perspektif syari'ah. Agama adalah puncak pencapaian kesejahteraan (sa'adab) lahir dan batin, sedangkan ilmu adalah salah satu jalan atau sarana (washilab) menuju puncak pencapaian kebahagiaan tersebut. Oleh karena itu perlu adanya keseimbangan di antara keduanya, sesuai dengan pernyataan Einstein,"Science without religion is blind, religion without science is lame".

Hal itu sejalan dengan pernyataan Arkoun bahwa agama tidak mengubah kenyataan, tidak juga merupakan usaha pembaharuan. Agama merupakan puncak pencapaian, yang mengubah atau melakukan pembaharuan adalah manusia itu sendiri dengan iptek yang bersumber dari ajaran tauhid. ${ }^{12} \mathrm{Di}$ samping itu dalam dunia pendidikan sekarang terkesan tidak adanya hubungan harmonis antara ilmu ekonomi dengan agama. Dengan demikian terkesan agama terpisah dengan ilmu ekonomi, padahal antara agama dengan ekonomi itu saling mendukung dan menunjang keselarasan kehidupan di era globalisasi. Hal itu dikarenakan terdapat interpretasi bahwa agama bertujuan untuk akhirat dan ekonomi untuk hidup di dunia. ${ }^{13}$

Dengan kondisi ketidakharmonisan hubungan ilmu pengetahuan dengan agama serta tidak adanya kelanjutan ilmu-ilmu ekonomi yang sudah diperoleh dalam lingkungan keluarga, maka begitu seseorang mendapatkan pengetahuan hanya berorientasi pada pengembangan kecerdasan akal atau Intelegensi Quotient (1Q), akan menghasilkan jiwa materialistik karena muatan materi ajarnya

Adapun Kant mengartikan pendidikan sebagai care, discipline and instruction. Lihat ibid., p. 377. "Mastuhu (2003), Menata Ulang Pemikiran Sistem Pendidikan Nasional dalam Abad 21, Yogyakarta: Safiria Insania Press, p. 31.

${ }^{12}$ M. Atkoun (1994); Nalar Islam Modern Berbagai Tantangan dan Jalan Baru, Jakarta: INIS, p. 71.

${ }^{13}$ Bukti bahwa ilmu ekonomi baru diberikan peserta didik di tingkat menengah, itupun ilmu ekonomi kapitalis (konvensional) padahal ilmu agama sudah diberikan dalam keluarga, walaupun pendidikan ekonomi itu secara tidak langsung sudah diberikan dalam keluarga misalnya hidup sederhana, menabung, prinsip-prinsip jual beli, namun hal itu tidak ada proses kelanjutan dalam ilmu ekonomi di lembaga pendidikan formal. 
mengesampingkan kecerdasan emosional atau Emotional Quotient (EQ) dan kecerdasan spiritual atau Spritual Quotient ( $S Q$ ) bagi pendidikan umum. Akan tetapi dalam pendidikan Islam SQ menduduki proporsi lebih besar bila dibandingkan dengan IQ dan EQ. Dalam tulisan ini sedikit dipaparkan bagaimana bentuk pendidikan berwajah insani yang mampu mengoptimalkan kecerdasan IQ, EQ dan SQ tersebut.

\section{B. Diskursus Kecerdasan Intelektual, Emosional dan Spiritual}

Ketiga kecerdasan tersebut harus diserap dengan baik oleh peserta didik untuk menjamin kesuksesan peserta didik, sehingga out put pendidikan tersebut bisa dikatakan pendidikan berwajah insani. Menurut penulis tidak ada pilihan paling dominan untuk menjamin kesuksesan peserta didik, akan tetapi terdapat tahapan-tahapan untuk memperoleh ketiga kecerdasan tersebut. Tahapan awal dalah proses kecerdasan IQ, kemudian SQ, baru kemudian EQ sebagai bekal mewujudkan insan kamil yang mempunyai tugas sebagai kbalifatullab fil ardhi agar mampu menjaga dan mengembangkan sumber-sumber daya yang ada.

Pada dasarnya manusia telah mendapatkan SQ dalam lingkungan keluarga, kemudian dilanjutkan dengan proses IQ lewat proses belajar di bangku sekolah. Dengan hanya bekal intelektual, bukan merupakan jaminan bahwa manusia sukses dalam menghadapi kehidupan di era globalisasi. Manusia juga masih membutuhkan kecerdasan EQ dan SQ. Dengan ketiga kecerdasan tersebut manusia dapat menangkap kebenaran berdasarkan syari'ah dan mengimplementasikannya dalam kehidupan.

Dengan demikian ketiga kecerdasan itu sangat berperan dalam mengantarkan keberhasilan seseorang untuk mengarungi kehidupan global. Tetapi sulit bagi manusia untuk memperoleh ketiga kecerdasan itu. Ada kalanya manusia mempunyai kecerdasan intelektual rendah, sehingga perlu dipupuk kecerdasan emosionalnya dan demikian pula sebaliknya. Ada seorang lulusan dari perguruan tinggi dengan IPK rendah tetapi setelah masuk dunia kerja malab menjadi sukses. Hal itu menurut Daniel Goleman disebabkan karena mahasiswa tersebut memiliki kecerdasan emosional yang tinggi sehingga ia mampu mengelola diri sendiri, mampu berhubungan dengan orang lain, dan mampu bekerja dalam kelompok. ${ }^{14}$ Akan tetapi sebaliknya, ada mahasiswa yang IPK-nya tinggi tetapi tidak berhasil dalam dunia kerja. Untuk mengetahui kedudukan ketiga kecerdasan itu, penulis akan memaparkannya di bawah ini:

1. Hubungan Kecerdasan Intelektual, Emosional, dan Spiritual

Manusia lahir ke dunia pasti mempunyai beberapa potensi yang bisa

${ }^{14}$ Daniel Goleman (1999), Kecerdasan Emosi untuk Mencapai Puncak Prestasi. Gramedia Pustaka Utama, pp. 34-35. 
dikembangkan dalam kehidupannya, seperti potensi ketauhidan dan emosional atau perasaan yang saling berhubungan. Ketika bagian emosi yang rusak, maka kemampuan rasional atau intelektual tetap utuh. Kondisi emosi rusak, manusia masih tetap mampu berbicara, menganalisa, dan berprestasi baik melalui tes IQ, bahkan dapat memprediksi bagaimana seseorang harus bertindak. Namun demikian, dalam kondisi tragis tersebut, orang ini tidak mampu membuat keputusan dalam dunia nyata, tidak mampu berinteraksi secara baik dengan orang lain dan bertindak secara layak. Ia memang dapat menyusun rencana jangka pendek maupun panjang demi masa depannya, tetapi tidak dapat membuat pertimbangan yang akhirnya tidak mendapatkan kesuksesan.

Teknologi yang berusaha menggambarkan kerja otak (brain imaging) dan kini membantu para pakar untuk memetakan hati manusia, menunjukkan bahwa bagian rasional dan emosional otak saling bergantung satu sama lain. ${ }^{15}$ Lalu muncullah pernyataan Joseph Le Doux dari New York University pada awal tahun sembilan puluhan bahwa pesan indera manusia seperti mata dan telinga mula-mula dicatat oleh struktur otak yang paling banyak terlibat dalam kenangan emosional amygdala sebelum masuk ke dalam neokorteks. ${ }^{16}$ Pernyataan tersebut berarti bahwa kecerdasan emosional berkaitan dengan rasional (intelektual). Itu sebabnya secara psikologis ketika pusat-pusat emosional di otak terbuka, maka seluruh intelegensi manusia mengalami korsleting (terputus sejenak). Emosi dan pikiran merupakan dua bagian dari satu keseluruhan. Itulah sebabnya istilah baru diciptakan untuk menggambarkan kecerdasan hati atau emosional yaitu dengan sebutan EQ.

IQ dan EQ merupakan dua sumber sinergis. Sehingga tanpa kecerdasan emosional, manusia menjadi tidak lengkap dan tidak efektif. Seharusnya memiliki EQ tinggi setidak-tidaknya sama pentingnya dengan mempunyai IQ tinggi. Keberhasilan dalam kehidupan tidak hanya ditentukan oleh IQ saja, tetapi justru kecerdasan emosional dan kecerdasan spirituallah yang memegang peranan penting. Dengan demikian' kecerdasan intelektual dan emosional perlu dimiliki. Kemudian pada akhirnya harus diserahkan pada kekuasaan Allah (SQ). Kecerdasan intelektual (IQ) saja tidak dapat bekerja dengan sebaik-baiknya tanpa kecerdasan emosional (EQ) dan kecerdasan spiritual (SQ).

is Jeanne Segal (1999), Meningkatkan Kecerdasan Emosional: Pedoman Praktis Program antuk Memperkuat Naluri dan Emosi Anda, Jakarta: Citra Aksara, p. 4.

${ }^{16}$ Ibid., p. 5. 
2. Posisi Kecerdasan Intelektual, Emosional dan Spiritual

Untuk mencapai keberhasilan hidup hendaknya seseorang mampu menyeimbangkan ketiga kecerdasan itu. Bagaimanapun kehidupan manusia tetap harus dilandasi dengan kecerdasan spititual untuk dapat sukses.

a. EQ rendah dan IQ tinggi

IQ dapat mengatakan banyak hal secara obyektif, tetapi tidak mampu memberitahu bagaimana perasaan, sedangkan perasaan dapat membuat manusia menjadi bijaksana. ${ }^{17}$ IQ tanpa EQ bisa saja mencetak nilai bagus, namun tidak mampu untuk menjalani kehidupan termasuk dalam dunia pendidikan. Dengan demikian kecerdasan emosional memerlukan emphati untuk memahami orang lain, sedangkan kecerdasan intelektual hanya mampu memprediksi prestasi di atas kertas saja.

Dalam penelitian filsafat politik di University of Otago New Zealand James R. Flyn menyatakan bahwa IQ tinggi seorang mahasiswa dapat diketahui berdasarkan IPK. Ironisnya, kecerdasan emosional dan sosial walaupun intelektual mahasiswa tinggi terus merosot tajam. Hal ini disebabkan karena perilaku yang lebih buruk seperti tawuran dan banyaknya kenakalan lainnya. ${ }^{18}$ Dengan demikian walaupun generasi anak-anak semakin cerdas secara intelektual, namun secara emosional dan sosial makin merosot. Jadi jika kita ukur EQ menggunakan statistik kesehatan mental dari faktorfaktor sosiologi tersebut, akan terlihat bahwa dewasa ini anak-anak berperilaku jauh lebih buruk daripada generasi-generasi sebelumnya.

b. EQ tinggi dan IQ rendah

EQ merupakan kebutuhan sinergis, di mana hubungan pribadi dengan orang lain merupakan tanggung jawab untuk penghargaan diri maupun kepekaan terhadap lingkungan sosial. EQ tinggi membuat seseorang dapat mengalami berbagai perasaan yang muncul dan benar-benar membuat seseorang mengenal dirinya. ${ }^{19} \mathrm{EQ}$ memegang peranan penting dalam meningkatkan karit seseorang baik dalam keluarga, masyarakat, maupun lingkungan pendidikan.

EQ dapat membedakan sesuatu yang penting pada dirinya dan untuk orang lain, juga mengetahui perbedaan mana yang perlu dipertahankan dan mana yang perlu dikorbankan. ${ }^{20}$ Peningkatan EQ akan memberi kemampuan untuk berhubungan dengan orang lain. Manusia akan menjadi

${ }^{17}$ Ibid, p. 12.

${ }^{18}$ Lawrence E. Shapiro (1999), Mengajarkan Emosional Intelligent Pada Anak, Jakarta: Gramedia Pustaka Utama, p. 11.

${ }^{19}$ Jeanne Segal, op.cit., p. 5.

${ }^{20}$ Ibid., p. 9. 
pribadi-pribadi mulia dan menyenangkan dengan dibekali kecerdasan emosional tinggi.

Dengan demikian seseorang yang memiliki EQ tinggi akan dapat hidup lebih mudah dan merasa nyaman dalam kehidupannya, lebih percaya diri dan lebih sukses dalam meniti karir. ${ }^{21}$ Banyak orang berpendapat bahwa kepribadian Franklin Delao Roosevelt yang dinamis dan optimisme luar biasa merupakan faktor paling penting dalam memimpin Amerika mengatasi masa-masa kritis zaman depresi dan Perang Dunia II. Oliver Wendell Holmes menggambarkan Roosevelt sebagai orang yang memiliki kecerdasan intelektual kelas dua, tetapi memiliki kecerdasan dan kematangan emosional kelas satu. Hal yang sama juga ditujukan untuk John F. Kennedy, yang memuat banyak sejarah, lebih banyak memimpin Amerika dengan hatinya daripada dengan kepalanya. ${ }^{22}$ Oleh karena itu kecerdasan emosional dapat dijadikan sebagai fondasi bagi anak-anak kita untuk menjadi orang dewasa yang bertanggung jawab, peduli pada orang lain dan produktif.

Kecerdasan emosional mempunyai peranan penting dalam keberhasilan pendidikan. Kecerdasan emosional itu secara umum meliputi tiga paradigma sebagai dasar, yaitu; Pertama, bagaimana memandang diri sendiri seperti berkepribadian positif dan percaya diri. Kedza, bagaimana memandang orang lain seperti dengan menghargai. Ketiga, bagaimana memandang pekerjaan seperti bangga dan antusias.

c. SQ di tengah-tengah IQ dan EQ

Kecerdasan emosional (EQ) dan kecerdasan intelektual (IQ) tetap membutuhkan kecerdasan spiritual (SQ). Dalam rangka menjembatani manusia untuk dapat mengarungi kehidupan seperti meniti karir contohnya, perlu adanya keseimbangan baik jasmani maupun rohani. Maka EQ dan IQ memerlukan SQ. Menurut penulis, SQ dapat diungkapkan dengan sebuah kata SHALIH (Sabar, Hikmah, Amal shaleh, Lidah, Ilmu dan Hati nurani). Dengan ketiga kecerdasan itu, maka manusia akan berhasil dengan gemilang. ${ }^{23}$

Bila EQ dan IQ dilandasi dengan SQ, maka segala sesuatu akan lebih baik, sebab semua manusia dalam meniti karir, contohnya, harus mempunyai sifat-sifat SHALIH yang penjelsannya sebagai berikut:

1. Sabar

Potensi sabar pada manusia yang memiliki kedua kecerdasan (EQ dan

${ }^{21}$ Lawrence E. Shapiro, op.cit., p. x.

${ }^{22}$ Ibid., p. 9.

${ }^{23}$ Stephen R. Copey (1997), Seven Habith of Highly Effective People, Jakarta: Bina Rupa, p. 7. 
IQ) merupakan keteguhan hati dalam hal menghadapi cobaan dan kesulitan hidup di dunia. Dengan kesabaran, seseorang lebih memahami hidup dan dapat menggunakan kecerdasan intelektual serta emosionalnya dalam mengatasi permasalahan yang dihadapi. Sebagaimana dalam surat al-Baqarah ayat 153 Allah berfirman:

Hai orang-orang yang beriman, carilab pertolongan dengan sabar dan mengerjakan salat. Sesunggubnya Allab bersama-sama orang-orang yang sabar. (QS. al-Baqarah: 153).

Ayat di atas menjelaskan bahwa ibadah harus dipahami sebagai bentuk kesatuan antar tujuan yang bersifat ritualistic religius dengan tujuan yang bersifat duniawi. Hal itu sejalan dengan istilah Amien Rais yang menyatakan bahwa ibadah sebagai purifikasi ruhani di samping secara fisik tetap harus membersihkan badan seperti dengan berwudlu lima kali sehari ketika hendak shalat. Dengan purifikasi ruhani itu Allah akan menjaga hambanya supaya tidak tercebur pada perbuatan dosa. ${ }^{24}$

2. Hikmah

Hikmah adalah ilmu pengetahuan yang sangat dalam dan tidak saja dengannya manusia mampu memahami kenyataan-kenyataan yang ada tetapi juga mampu memahami apa di balik kenyataan tersebut. Seseorang yang memiliki kecerdasan intelektual dan emosional secara optimal, maka ia akan mampu mengambil hikmah dari semua yang telah terjadi lalu menyerahkan hasil semua itu pada Allah. Oleh karena itu seseorang yang mampu memanfaatkan ketiga kecerdasan dengan komplit (IQ, $E Q$, $\mathrm{SQ}$, maka ia akan berpasrah diri bila semua perbuatan sudah diniati. Akhirnya ia mampu membuka.diri dan bertukar pikiran dengan orang lain yang berkaitan dengan kegagalannya. Hal ini sesuai dengan firman Allah surat an-Nahl ayat 125:

Ajaklab mereka kepada jalan Tuban dengan bikmab dan mengajarkan yang baik, dan bertukar pikiranlab dengan mereka menurut cara yang sebaik-baiknya, sesunggubnya Tuban engkau lebib tabu siapa yang sesat jalannya, dan lebib mengetabui pula orang-orang yang menuruti jalan yang benar. (QS. An-Nabl: 125).

3. Amal shaleh

Biasanya orang yang beramal shaleh adalah orang yang beriman. Hal ini menggambarkan bahwa keimanan harus dinisbatkan dalam hati, dinyatakan melalui lisan, dan benar-benar diungkapkan dalam perbuatan nyata sehari-hari. Amal shaleh ada yang bersifat pribadi dan kolektif.

${ }^{24}$ Amien Rais (1998), Taubid Sosial, Bandung: Mizan, p. 61. 
Tidak setiap aktifitas atau pemberian untuk kesejahteraan orang lain itu dapat dianggap sebagai amal shaleh karena belum tentu dimotivasi dengan niat. Karena bisa saja seorang kafir seakan berbuat amal shaleh tetapi tanpa motivasi yang benar, maka dia akan menipu banyak orang bahkan dirinya sendiri. Amal shaleh menurut lslam harus dilakukan dengan motivasi niat yang benar, yakni lillabi rabbil alamin. ${ }^{25}$ Oleh karena itu tepatlah jika seseorang mau meningkatkan kecerdasan spiritualnya harus dilakukan dengan jalan amal shaleh.

4. Lidah

Lidah yang dimaksud adalah kemampuan untuk berbicara, dalam arti menyampaikan informasi kepada orang lain ketika berdialog, memberi jawaban atas pertanyaan yang datang dari orang lain, serta kegiatan komunikasi lainnya. Kemampuan komunikasi sangat penting dalam kehidupan manusia, bahkan dapat dikatakan merupakan unsur penentu keberhasilan dan kegagalan hubungan antar manusia. Hal ini dapat diterapkan bagi setiap orang. Seseorang yang mengimplementasikan kecerdasan yang dimiliki baik intelektual, emosional, maupun spiritualńya akan menerapkan dan memanfaatkan lidah melalui interaksi edukatif.

5. Ilmu

Maksudnya adalah setiap orang yang mempunyai pengetahuan sesuai dengan kemampuannya untuk melihat dirinya dan segala kejadian di dunia termasuk perkembangan masyarakatnya di bawah cahaya nur ilabi. Dengan demikian ia tidak hanyut dalam pengejaran kebendaan dan materialisme berlebihan. Hanya dengan iman dan ilmu, manusia belum bermakna kecuali dilengkapi dengan amal. Pepatah Arab mengatakan; al-ilmu bila 'amalin kasyajarin bila tsamarin. Oleh karena itu amal merupakan perwujudan dari iman dan ilmu seseorang.

6. Hati nurani

Hati nurani letaknya ada dalam dada manusia yang dapat membedakan mana yang baik dan benar. Namun hati nurani manusia tidak sepenuhnya mampu memahami jalan menuju Allah secara langsung melalui peristiwa di jagat raya ini. Sebaliknya, hati nurani manusia hanya mampu memahami tanda-tanda kekuasaan-Nya saja, maka di hati nuranilah letak kecerdasan emosi yang dapat digunakan untuk memahaminya. Dengan demikian hanya seseorang yang meningkatkan kecerdasan spiritualnyalah yang berkeyakinan bahwa hanya Allah yang maha kuasa. 


\section{Strategi Pengembangan Kecerdasan IQ, EQ, SQ dalam Pendidikan}

Pada umumnya dunia pendidikan hanya mendominasi otak sebelah kiri, sedangkan otak sebelah kanan kurang tersentuh. Belahan otak kiri melakukan bagian logis atau verbal, sedangkan belahan kanan lebih intuitif. ${ }^{26}$ Tentu saja idealnya pendidikan adalah pendidikan yang mampu mengolah dan mengembangkan ketiga kecerdasan di atas secara optimal agar mempunyai perlintasan yang baik kedua belahan otak tersebut. Menurut psikolog Seto Mulyadi, ada tujuh aspek kecerdasan yakni bahasa, logika, visual, musikal, kinestetik, interpersonal dan intrapersonal. Yang sering disebut sebagai kecerdasan intelektual adalah dua yang pertama, yakni bahasa dan logika. Padahal tidak semua orang jago dalam kedua bidang itu, sehingga dalam lingkungan pendidikan materi ajarnya hanya tertumpu pada aspek bahasa dan logika, ${ }^{27}$ yang hanya didominasi oleh otak kiri sedangkan aspek yang lain diabaikan, ${ }^{23}$ tetapi setidaknya aspek empat itu hendaknya materi ajarnya menyentuh pengembangan kecerdasan emosi, dan kecerdasan spiritual di setiap lembaga pendidikan.

Dengan demikian pendidikanlah yang mampu mewujudkan kecerdasan komplit pada setiap manusia. Oleh karena itu pendidikan membutuhkan model yang tidak cukup hanya mampu mengembangkan kecerdasan akal atau intelektual (IQ) saja namun juga hendaknya yang juga mampu mengembangkan kecerdasan emosional (EQ), dan kecerdasan spiritual (SQ). Model pendidikan yang memuat materi ajar ketiga kecerdasan tersebut agar tidak mengalami kegagalan dan kesesatan peserta didiknya dalam menghadapi kehidupan modern di era globalisasi yang penuh tantangan ini, sehingga tidak hanya mengandalkan IQ. Kondisi konkrit yang terjadi sekarang ini sejalan dengan pernyataan Daniel Goleman, bahwa kehidupan bukan hitam putih, bukan sekedar "if thie then that", bukan sekedar urut-urutan sebab akibat yang deterministik, jika begitu kemudian begitu. Banyak hal atau kejadian yang secara logika benar tetapi perasaan menyatakan bahwa hal itu tidak benar, karena itulah seringkali diperlukan kecerdasan akal didampingi kecerdasan emosional. ${ }^{29} \mathrm{Di}$ samping kecerdasan emosional perlu juga didampingi pula kecerdasan spiritual agar mampu menangkap hikmah kehidupan dan memahami tanda-tanda kekuasan Allah dan apa yang terjadi secara pasti dan tidak suatu makhluk pun yang mampu mengelak atau keluar dari padanya.

EQ letaknya ada dalam dada manusia, tepatnya berakar dalam hati nurani yang amat dalam dan kesadaran diri. Oleh karena itu pendidikan hendaknya mampu

\footnotetext{
${ }^{26}$ Stephen R. Covey, op.cit., p. 121.
}

${ }^{27}$ Kelompok materi ajarnya meliputi bahasa Indonesia, ilmu pengetahuan alam, matematika, kimia, biologi, geografi, ilmu ukur ruang, statistik dan ilmu-ilmu eksakta lainnya.

${ }^{28}$ Stephen R. Copey, op.cit., p..121.

61.

"Daniel Goleman (1999), Working with Emotional Intellegence, USA and Canada: Bantam Book, p. 
mengembangkan kecerdasan emosional melalui tiga tahapan. Pertama kecerdasan emosi, karena emosi meliputi perasaan-perasaan jiwa manusia, maka materi ajarnya harus dikembangkan dengan ilmu psikologi, sosiologi, filsafat, ilmu-budaya dan sosial, antropologi, humaniora, informasi dan komunikasi agat mampu mengantarkan peserta didik memanfaatkan nilai-nilai luhur dan mengambil keputusan dalam kehidupan bersama baik di lingkungan sempit maupun lingkungan luas. Kedua, Penilaian diri, yang bertujuan untuk mengantarkan peserta didik untuk memiliki kemampuan belajar dari pengalaman. Ketiga, percaya diri, bertujuan untuk mengantarkan peserta didik memiliki kemampuan dan keberanian menyatakan kebenaran. Karena pendidikanlah yang mempunyai strategi untuk mengembangkan kecerdasan emosional itu, dengan dalih bahwa kecerdasan emosional merupakan "the inner rudder", kekuatan dari dalam, sifatnya alami, dan dapat berkembang dengan kuat melalui akumulasi pengalaman panjang dan beragam.

Adapun kecerdasan spiritual merupakan potensi yang dimiliki oleh setiap manusia. Dengan kata lain fittah seseorang harus dikembangkan melalui pendidikan. Adapun fitrah yang dimaksud di sini adalah termasuk juga potensi ketauhidan. ${ }^{30}$ Oleh karena pendidikanlah yang paling strategis untuk selalu mengasah potensi ketauhidan tersebut agar mampu mengantarkan peserta didik untuk menyakini kebesaran Allah. Pengasahanya lewat proses belajar mengajar materi ajar apa saja dikaitkan dengan kekuasaan Allah atau ilmu yang ada hubungannya dengan ilmuilmu agama misalnya sesuai dengan syariah.

Dengan demikian di zaman globalisasi ini, model pendidikan harus mampu mengembangkan kecerdasan secara komplit, tidak hanya kecerdasan akal atau intelektual (IQ), tetapi juga kecerdasan emosional (EQ) dan kecerdasan spiritual (SQ). ${ }^{31}$ Dengan ketiga kecerdasan itu dikembangkan dalam model pendidikan berwajah insani maka akan menghasilkan sejumlah out put yang tangguh dalam menghadapi hidup di era globalisasi karena memang membutuhkan manusia-manusia akademik atau knowledge sociely dan membutuhkan kecerdasan komplit sebagai modal agar cerdas, tajam dan peka dalam menghadapi setiap masalah.

\section{Penutup}

Untuk menghadapi zaman yang penuh keterbukaan, hendaknya peserta didik diimbangi dengan model pendidikan berwajah insani yang mampu mengembangkan kecerdasan komplit (IQ, EQ, SQ). Dengan demikian tidak hanya mengembangkan kecerdasan intelektual saja, karena hal itu akan menimbulkan dampak negatif dan kemungkinan besar tidak mampu mengatasi problematika yang penuh dengan

${ }^{30}$ Abdurrahman Shaleh Abdullah (1994), Teori-teori Pendidikan Berdasarkan al-Qur'an, Jakarta: Rineka Cipta, p. 59.

${ }^{31}$ Mastuhu, op.cit., p. 97. 
keterbukaan, bahkan secara akumulatif dapat menimbulkan masalah besar. Terjadinya kehancuran dunia dapat dikarenakan model pendidikan yang hanya bertumpu pada IQ dan berorientasi pada sifat materialistik semata. Oleh karena itu kecerdasan intelektual (IQ) hendaknya diimbangi kecerdasan emosional (EQ) yang berdampingan dengan kecerdasan spiritual (SQ). Dengan demikian, setiap out put dapat diharapkan mampu mengendalikan tata pikir yang akalnya lebih jujur, mampu mengembangkan kerja sama dengan berbagai pihak, saling menghargai dan menguntungkan karena kenyataannya tidak ada satu masalahpun yang tidak terkait dengan yang lain atau tidak melibatkan pihak lain. Selain itu, banyak hal yang secara akal dan menurut perhitungan matematik sudah benar; tetapi dapat membuka peluang yang tidak jujur. Oleh karena itu tetap diperlukan kecerdasan spiritual untuk mengatasinya. Untuk mengatasi kebobrokan moral dan meningkatkan kualitas manusia dibutuhkan kecerdasan intelektual (IQ) dan kecerdasan lainnya yaitu kecerdasan emosional (EQ) dan kecerdasan spiritual (SQ) sebagai satu kesatuan dalam pendidikan berwajah insani.

\section{DAFTAR PUSTAKA}

Abdurrahman Shaleh Abdullah (1994), Teori-teori Pendidikan Berdasarkan al-Qur'an, Jakarta: Rineka Cipta.

Azwar Anas (1993), Kompetensi Perguruan Tinggi Islam Swasta dalam Pembangunan Jangka Panjang Tabap Kedua, Yogyakarta: Tiara Wacana.

M. Arkoun (1994), Nalar Islam Modern Berbagai Tantangan dan Jalan Bars, Jakarta:

INIS.

Covey, Stephen R. (1998), Seven Habith of Highly Effective People, Jakarta: Bina Rupa. -Goleman, Daniel (1999), Kecerdasan Emosi untuk Mencapai Puncak Prestasi, Jakarta:

Gramedia Pustaka Utama.

Mansur (2001), Diskursus Pendidikan Islam, Yogyakarta: Global Pustaka Utama. (2005), Mendidik Anak Sejak dalam Kandungan, Yogyakarta: Mitra Pustaka. Mastuhu (2003), Menata Ulang Pemikiran Sistem Pendidikan Nasional dalam Abad 21, Yogyákarta: Safiria Insania Press.

Price, Kingsley. (1965), Educational and Philosopbical Thougbt, USA: Allyn and Bacon. Amien Rais (1998), Taubid Sosial, Bandung: Mizan.

Ghulam Nabi Saqib (1983), Modernization of Muslim Education in Egypt, Pakistan, and Turkey, Lahore: Islamic Book Service.

Segal, Jeanne (1999), Meningkatkan Kecerdasan Emosional, Pedoman Praktis Program untuk Memperksiat Naluri dan Emosi Anda, Jakarta: Citra Aksara.

Shapiro, Lawrence E. (1999), Mengajarkan Emosional Intelligent Pada Anak, Jakarta:

Gramedia Pustaka Utama. 